\title{
THE USE OF EPIDURAL BLOCK IN ACUTE PANCREATITIS: A REPORT OF EIGHT CASES
}

\author{
R. A. BROWNE, M.B., CH.B., F.F.A.R.C.S. (ENG.), AND \\ E. J. AsHWORTH, M.B., B.S.(LOND.)
}

Pancreatrtis is a relatively common condition. It has been estimated by Blumenthal and Probstein ${ }^{1}$ that the incidence is about 1 in 600 admissions $(0.16$ per cent), based on the routine determination of serum amylase. The incidence of acute necrotizing pancreatitis in an autopsy series of 41,333 cases reported by $\mathrm{McWhorter}^{2}$ in 1952 was approximately 4 per thousand ( 0.4 per cent).

The pancreas normally secretes a clear, colourless, and slightly mucoid fluid containing enzymes (trypsin, chymotrypsin, amylase, maltase, and lipase) which are concerned with digestion of protein, carbohydrates, and fat in the intestine. The action of these enzymes outside their normal environment accounts for the three major components of acute pancreatitis, namely $(a)$ parenchymatous necrosis, (b) fat necrosis, and (c) haemorrhage.

The pain of acute pancreatitis in its most severe form is excruciating and unrelenting. The patient writhes about in bed, shouting aloud in agony. Frequent doses of analgesics seem to alleviate the pain only very temporarily, and large doses are required. It is in this type of case that the use of some form of regional block would be most useful in controlling the extreme discomfort of the patient. Pain in the epigastrium, radiating through to the back, is the most prominent and distressing symptom of this condition, and the patient appears ashen grey in colour, breathing shallowly and rapidly and sweating profusely. In its most severe form, the shock may be so profound that death ensues rapidly. The pain is constant and is so relentless that the patient cannot rest. It thus leads to mental and physical exhaustion and contributes to the shock which is always present.

\section{Nerve Supply of the Pancreas}

The pancreas receives both sympathetic and parasympathetic nerves. The sympathetic nerves reach the pancreas through the greater and lesser splanchnic trunks arising from the fifth to tenth or eleventh thoracic sympathetic ganglia; the major nerve supply is through the greater splanchnic nerve. Parasympathetic fibres travel to the gland through the vagi and terminate in intrinsic pancreatic ganglia. These fibres are secretomotor. All the nerves to the pancreas, both afferent and efferent, pass through the coeliac plexus. Sympathetic preganglionic fibres reach the coeliac or superior mesenteric ganglia, from which postganglionic fibres proceed along vessels to the pancreas (Fig. 1). Afferent pain fibres reach dorsal root ganglia from the pancreas by hitch-hiking along the sympathetic nerves

"Department of Anaesthesia, Hamilton Civic Hospitals, Hamilton, Ontario. 


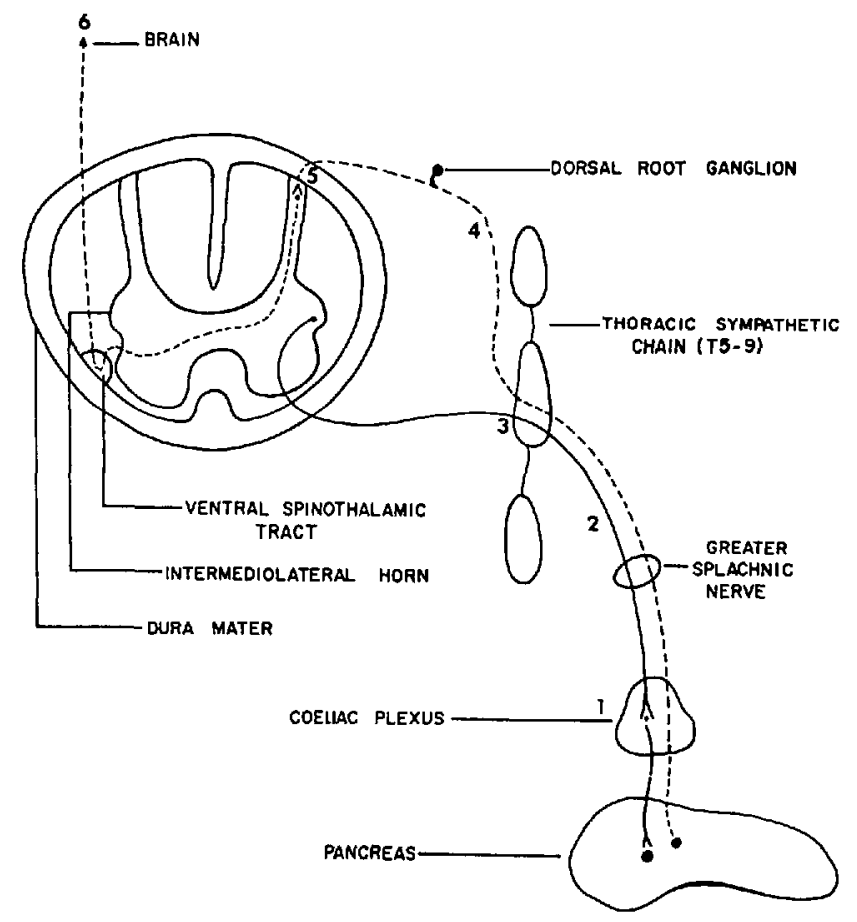

Figure 1. Sympathetic and afferent nerve supply of the pancreas.

through the coeliac ganglia (Fig. 1). These pain fibres travel only with the greater splanchnic nerves.

It can be readily seen from Figure 1 that the following possibilities exist for controlling the pain of acute pancreatitis:

1. Block of the coeliac plexus (splanchnic block). This was carried out by Marion, ${ }^{3}$ but is not a convenient method as it requires repeated injections into the coeliac plexus.

2. Unilateral and bilateral thoraco-lumbar sympathectomy and splanchnicectomy. ${ }^{4}$ While this may be useful in relieving pain in chronic pancreatitis, it is not practicable in acute pancreatitis as these patients are very ill and do not tolerate surgery well.

3. Paravertebral sympathetic block. ${ }^{6}$ This technique, while useful, is cumbersome and unpredictable in its effectiveness, and requires repeated injections. ${ }^{6}$

4. Epidural block. ${ }^{6,7}$ This would appear to be a useful method for producing prolonged and continuous pain relief.

5. Spinal block. This method, while producing relief of pain, is not suitable for prolonged use because of the possibility of infection in the subarachnoid space, and of nerve damage.

6. Narcotic analgesics, e.g. morphine, meperidine, that act centrally on the central nervous system, mainly by altering the emotional reaction to pain and to a lesser extent by altering the perception of pain. ${ }^{8}$ 
It has been found in severe cases that large doses of analgesics are required, and even these are sometimes not satisfactory. In one of our patients, a young man of 35 years (case no. 3), $800 \mathrm{mg}$ of meperidine was administered over a 24-hour period, and even this dosage was inadequate. He subsequently received a continuous epidural block with good pain relief.

This paper describes the use of epidural block in eight patients admitted to the Hamilton General Hospital during 1967 and 1968. All received repeated doses of analgesics which failed to provide satisfactory pain relief. During this period there were 192 admissions of acute pancreatitis, so that this sample represents 4.2 per cent of our admitted cases. In some of these cases, pushing the analgesic doses further would have resulted in marked respiratory depression and necessitated assistance to or control of respiration.

\section{Technique}

With the patient lying in the lateral position, a Skinner ${ }^{9}$ portex epidural catheter was introduced into the epidural space at L 1-2 or L 2-3 level. The loss-ofresistance method was used to identify the epidural space using a syringe loaded with air or saline. The catheter was pushed cephalad until it was judged that its tip lay opposite the T $6-8$ segments. It was then strapped over the patient's back and brought over one shoulder. Fifteen to twenty cc of 0.5 or 1 per cent Xylocrine containing 1 part in 200,000 adrenaline was then injected. Approximately one hour later, when the first twinges of pain returned, a drip of 1 per cent Xylocaine with adrenaline was started at a rate of 10 to 15 drops per minute. A microdrip was used ( $60 \mathrm{drop} / \mathrm{cc}$ ), thus administering 10 to $15 \mathrm{cc}$ of solution each hour ( 100 to $150 \mathrm{mg}$ Xylocaine).

Instructions were given to the nurses in the intensive care unit to stop the drip immediately if: (a) the systolic blood pressure fell below a definite level (usually to the patient's initial diastolic pressure), $(b)$ the patient appeared excitable or tremulous, or developed convulsions, $(c)$ any depression of respiration or of consciousness occurred. During the first two hours, quarter hourly blood pressure readings were carried out, and if they remained stable, then hourly readings were taken thereafter.

\section{Results}

Results are classified in Table I. They show that seven of our eight patients experienced good pain relief. In one patient it was fair, as this patient required additional analgesics during the two-hour period of the block. Subsequently the block was discontinued, and only analgesics were used. The average duration of the block was two and one-half days, the longest-lasting was seven days, and the average dose of Xylocaine per day was $931 \mathrm{mg}$. Six of the eight patients were discharged from hospital after periods varying between seven days and seven months. Two patients died (cases no. 1 and 2), one after two days and the other after 35 days, in spite of the good pain relief achieved by the epidural block. Post-mortem examination in both of these cases revealed extensive, widespread 
BROWNE \& ASHWORTH: EPIDURAL BLOCK IN ACUTE PANCREATITIS

TABLE I

Results of Epidural Block in Eight Cases of Acute Pancreatitis

\begin{tabular}{|c|c|c|c|c|c|c|}
\hline Case & Sex & Age & $\begin{array}{l}\text { Duration } \\
\text { of block* }\end{array}$ & $\begin{array}{l}\text { Total } \\
\text { Xylocaine dose } \\
\text { (mg)† }\end{array}$ & Pain relieff & Mortality \\
\hline 1 & $\mathrm{M}$ & 68 & 5 hours & 350 & good & died 2 days later \\
\hline$\overline{2}$ & $\mathrm{M}$ & 58 & 3 days & 2,200 & good & died 35 days after block \\
\hline 3 & M & 36 & 7 days & 5,000 & good & discharged 7 months later \\
\hline 4 & M & 65 & 2 hoürs & 200 & fair & discharged 19 days later \\
\hline 5 & $\mathrm{M}$ & 43 & 3 days & 2,000 & good & discharged 11 days leter \\
\hline 6 & $\mathrm{~F}$ & 53 & 2 days & 2,000 & good & discharged 19 days later \\
\hline 7 & $\mathrm{~F}$ & 54 & 3 days & 2,800 & good & discharged 7 days later \\
\hline 8 & M & 71 & 2 days & 2,500 & good & discharged 11 days later \\
\hline
\end{tabular}

*Average $2 \cdot 1 / 2$ days.

†Average per day $931 \mathrm{mg}$.
†Good: No narcotic analgesic required. Fair: Small dose of narcotic analgesic required.

fat necrosis and ascites. The pancreas showed extensive haemorrhagic necrosis with marked oedema and fat necrosis in the surrounding tissues. In both cases the primary cause of death was reported as acute haemorrhagic pancreatitis.

\section{Complications associated with the method}

1. Hypotension. This occurred in three patients after the initial epidural injection. It was corrected by intravenous injection of $2-5 \mathrm{mg}$ methoxamine. A fall in blood pressure did not occur in any of the cases when the epidural drip was running.

2. Tremors. These were observed in four patients after the epidural drip had been running for some hours, and were presumed to be due to a high blood level of Xylocaine directly stimulating the central nervous system. The condition was corrected by stopping the drip temporarily. No convulsions occurred.

There were no cases of total spinal block.

\section{Discussion}

There appears to be a correlation between the intensity of the disease process and the severity of symptoms. ${ }^{1}$ Diagnosis rests on the demonstration of an elevated serum amylase level. At the other extreme, the disease may run a fulminating course with early death, and the diagnosis be made at autopsy.

\section{Criteria}

Certain criteria had to be fulfilled before these patients were accepted for an epidural block.

1. A history suggestive of acute pancreatitis with typical pain distribution.

2. Elevated serum amylase. All of the eight patients had serum amylases in excess of 500 units before the block was started, except for patient no. 3 . In this patient the diagnosis was proved by laparotomy before the block was initiated (Table II).

3. An electrocardiogram with no evidence of recent myocardial infarction. 
TABLE II

Serum Amylase Levels

\begin{tabular}{cc}
\hline \hline Case no. & Serum amylase \\
\hline 1 & 1,110 \\
2 & 2,730 \\
3 & 256 \\
4 & 745 \\
5 & 1,450 \\
6 & 770 \\
7 & 1,345 \\
8 & 620 \\
\hline
\end{tabular}

TABLE III

\begin{tabular}{cl}
\hline \hline Case no. & \multicolumn{1}{c}{ ECG report } \\
\hline 1 & st changes, possible digitalis effect \\
2 & old anterior infarction \\
3 & normal \\
4 & normal \\
5 & non-specific $T$-wave changes \\
6 & normal \\
7 & non-specific $T$-wave changes \\
\hline
\end{tabular}

Gottesman et al. ${ }^{10}$ described transient changes in the electrocardiogram of five patients with acute pancreatitis simulating those of coronary occlusion. Myocardial infarction enters the differential diagnosis, so any patient with gross electrocardiographic changes should not be given this block, as any hypotension would further prejudice the patient's chances of recovery. Table III shows the electrocardiogram reports in our series.

It is stressed that the diagnosis must be certain, since when pain relief is achieved, this symptom ceases to be of any further diagnostic value.

Before the diagnosis has been made with certainty, certain other conditions must be thought of in the differential daignosis: ${ }^{1}$ acute cholecystitis, perforated peptic ulcer, myocardial infarction, acute intestinal obstruction, acute appendicitis, acute generalized peritonitis, splenic rupture, renal colic, pneumonia, tabetic crisis, dissecting aortic aneurysm, mesenteric thrombosis.

\section{Other methods of treatment}

In addition to the relief of pain, other conservative methods must be undertaken in acute pancreatitis:

1. Treatment of shock. Hypotension and decreased blood volume are common accompaniments of acute pancreatitis. Elliott ${ }^{11}$ found significant reduction in blood volume in 71 per cent of severe cases and in 12.5 per cent of patients with mild pancreatitis. Defects averaged $1500 \mathrm{ml}$ and appeared in the first 24 hours. Early shock was due to massive haemorrhage. Blood transfusion and plasma volume expanders may be required, and in some cases the use of cortisone may be lifesaving. ${ }^{12}$ All of our patients received blood or plasma volume expanders, and patient no. 1 was given cortisone. 
2. Replacement of fluid and electrolytes. Edmondson et al..$^{13}$ have pointed out that a reduction in $\mathrm{Na}^{+}, \mathrm{K}^{+}, \mathrm{Ca}^{++}$, and $\mathrm{Cl}^{-}$often occurs. The use of Lactated Ringer's and Darrow's solutions ${ }^{1}$ has been recommended by Jones. ${ }^{14}$ All of our patients received Lactated Ringer's solution, potassium chloride $(20 \mathrm{mEq} q 6 \mathrm{~h}$ ) and calcium gluconate ( $1 \mathrm{gm} \mathrm{q} 8 \mathrm{~h}$ ) for two to three days.

3. Control of spasm of the sphincter of Oddi. This is often considered either a primary inciting or a contributing factor in the development of episodes of acute pancreatitis. ${ }^{1}$ Two groups of autonomic blocking agents may be helpful. Probanthine ( $15 \mathrm{mg} \mathrm{q} 6 \mathrm{~h}$ ) is a representative of the first group (similar in action to atropine); while ganglion blocking agents, e.g. hexamethonium (20-40 mg q 12 h) are in the second group. All of our patients received probanthine, but none were given hexamethonium as this is a very powerful hypotensive agent.

4. Temporary suppression of pancreatic secretion. Nothing should be given by mouth, as food stimulates pancreatic secretion. Continuous nasogastric suction by tube is employed.

5. Control of abdominal distension due to ileus, by suction.

6. Prevention of suppuration by the use of antibiotics. Our patients received Ampicillin or in some cases Neomycin.

7. Management of disturbances of carbohydrate metabolism. Glycosuria is common during an attack of acute pancreatitis, and insulin may be required to control it. Two of our patients, both of whom died (cases no. 1 and 2), required insulin.

\section{Surgical treatment}

The occasional patient may require surgery due to: $(a)$ development of a pseudocyst, (b) suppuration, or $(c)$ haemorrhage.

\section{SUMMARY}

A study is presented of the use of continuous epidural block for the relief of pain in eight cases of acute pancreatitis. This has been shown to be a satisfactory method of controlling the severe abdominal pain, but it is stressed that the patients must be selected. The diagnosis must be certain, the ECG negative for recent coronary infarction, and treatment for shock and electrolyte deficiency must already have been started.

On évalue la fréquence de la pancréatite aigue a environ 1 pour $600<0.16$ pour cent). Les enzymes contenues dans le liquide pancréatique sont la tryspine, la chymotryspine, lamylase, la maltase et la lipase. L'action de ces enzymes hors de leur milieu naturel explique la pathologie de la pancréatite aigue, spécialement la nécrose graisseuse et l'hémorragie.

La douleur est très vive et pour la soulager il faut quelquefois utiliser des doses considérables et répétées d'analgésiques. La douleur peut être si atroce qu'il en résulte un épuisement mental et physique. Pour ce groupe de malades, un genre de bloc régional serait très utile. 


\section{INNERVATION DU PANCREAS}

Le pancréas est innervé par (a) le sympathique, $(b)$ le parasympathique et (c) des fibres afférentes qui portent la sensation douloureuse suivant le trajet du sympathique par les nerfs du grand splanchnique ( T 5-T 10, Fig. 1). D’après la Figure 1 on voit immédiatement qu'il existe les moyens suivants de controler la douleur.

1. Le blocage du plexus coeliaque. ${ }^{3}$ Cette technique n'est pas pratique puisqu'elle exige des injections répétées.

2. La sympathectomie dorso-lombaire et la splanchnicectomie, ${ }^{4}$ impraticables chez les grands malades souffrant de pancréatite aigue.

3. Le blocage sympathique paravertébral ${ }^{5}$ demande les injections répétées.

4. Le blocage épidural continu. ${ }^{6,7}$ Cette technique semble utile.

5. Anesthésie rachidienne. Pas souhaitable pour usage prolongé à cause de la possibilité d'infection de l'espace sousarachnoidien et de lésions nerveuses.

6. Les narcotiques, v.g., morphine, mépéridine, qui agissent sur le système nerveux central. Dans les graves, même de grosses doses répétées sont insuffisantes.

Ce travail expose les résultats obtenus par l'anesthésie épidurale chez huit malades à l'hopital général de Hamilton au cours des années 1967 et 1968. Tous ces sujets ont reçu des doses répétées d'analgésiques sans soulagement satisfaisant de la douleur. Durant cette période, il y a eu 192 cas de pancréatite aigue, ce qui représente 5 pour cent de nos admissions.

\section{TechNique}

Le malade couché sur le côté, on introduit un catheter portex de Skinner ${ }^{9}$ dans l'espace épidural au niveau de L 1-2 ou L 2-3. On pousse le catheter céphalad jusqu'à ce que le bout soit aux environs de $T$ 6-T 8 , puis on le fixe. On injecte 15 à $20 \mathrm{cc}$ de Xilocaine 0.5 ou 1 pour cent. Lorsque les premières douleurs reviennent, on installe un goutte à goutte de Xilocaine à 1 pour cent au rythme de 10 à 15 gouttes par minute, en utilisant un "microdrip" (60 gouttes par cc). Ceci débite environ 10 à $15 \mathrm{cc}$ par heure, soit 100 à $150 \mathrm{mg}$ de Xilocaine.

Les infirmières de l'unité des soins intensifs ont l'ordre d'arrêter le goutte à goutte immédiatement si:

1. La pression sanguine systolique s'abaissait à un niveau déterminé (généralement la pression diastolique initiale du malade).

2. Le malade devient irritable, s'il présente du tremblement ou des convulsions.

3. On observe une diminution de la respiration ou de la conscience.

On inscrit la pression artérielle toutes les 15 minutes durant les deux premières heures; si elle est stable, on l'inscrit toutes les heures par la suite.

\section{RÉSULTATS}

Ils sont classifiés dans le Tableau I qui démontre que sept de nos huit malades ont éprouvé un bon soulagement de leurs douleurs. Chez un malade, l'amélioration fut passable; il a fallu lui administrer des analgésiques supplémentaires, et, au bout de deux heures, on a cessé le bloc épidural. 
La durée moyenne de l'épidurale a été de $2 \%$ jours, et la dose moyenne de Xilocaine par jour de $931 \mathrm{mg}$. Six des huit malades ont reçu leur congé de l'hopital après des périodes allant de sept jours à sept mois. Deux malades sont morts malgré un bon soulagement de leur douleur par l'anesthésie épidurale. A l'autopsie on a trouvé que les deux présentaient une pancréatite aigue extensive.

\section{Complications}

1. Trois cas ont présenté de l'hypotension après la première injection; hypotension corrigée par 1 à $5 \mathrm{mg}$ de vasoxyl par voie intra-veineuse.

2. Tremblement chez quatre malades causé vraisemblablement par un haut niveau de Xilocaine dans le sang; on a corrigé ce symptome en arrêtant temporairement le goutte à goutte. Il n'y eut pas de convulsions ni d'anesthésie rachidienne totale.

\section{Discussion}

Le diagnostic repose sur un taux élevé d'amylase dans le sérum.

\section{Critères}

Il fallait se baser sur certains critères:

1. Une histoire suggestive de pancréatite aigue avec distribution typique de la douleur.

2. Amylase du sérum élevée. Tous les malades, sauf le no 3, avaient une amylase supérieure à 500 avant l'installation du bloc. Pour ce cas no 3 , le diagnostic fut posé au cours d'une laporatomie.

3. Un ECG normal. Le Tableau III montre les ECG de nos malades. Il faut faire le diagnostic différentiel avec certaines autres pathologies: cholécystite aigue, ulcère peptique perforé, infarctus du myocarde, occlusion intestinale aigue, appendicite aigue, péritonite aigue généralisée, rupture de la rate, colique néphritique, pneumonie, crise de tabès, anévrisme disséquant de l'aorte, thrombose mésentérique.

\section{Autres modes de traitement}

Pour aider à soulager la douleur, il y a aussi d'autres méthodes:

1. Le traitement du choc. On peut avoir à donner des transfusions ou des produits qui augmentent le volume du plasma. A l'occasion la cortisone peut aider.

2. Le remplacement des liquides et des électrolytes est nécessaire à cause du taux réduit du sodium, du potassium, du calcium et des ions de chlorures. On a conseillé le lactate Ringer et solutions de Darrows. ${ }^{14}$

3. Le contrôle du spasme du sphincter d'Oddi. En ce cas, la Probanthine (15 $\mathrm{mg}$ toutes les six heures) peut être utile.

4. La suppression temporaire de toute sécrétion pancréatique. Rien par la bouche et succion gastrique continue.

5. Prévention de la distension abdominale par succion.

6. Les antibiotiques pour prévenir la suppuration.

7. S'il survient une glycosurie, on peut avoir à utiliser l'insuline. 
Traitement chirurgical

A l'occasion, on doit instituer un traitement chirurgical, si $(a)$ un pseudo-kyste se développe, $(b)$ une suppuration se produit, $(c)$ une hémorragie se produit.

\section{RÉSUMÉ}

Dans une étude de huit cas de pancréatite aigue, on a démontré que l'anesthésie épidurale est un moyen efficace de contrôler la douleur. Il faut choisir les malades pour ce traitement. L'ECG ne doit pas déceler d'infarctus récent. Le traitement du choc et de la déficience en electrolytes doit être déja commencé.

\section{REFERENCES}

1. Blumental, H. T. \& Probsten, J. G. Pancreatitis: A Clinical Pathologic Correlation. Chicago: Charles C Thomas (1959).

2. McWhorten, G. L. Acute Pancreatitis. Arch. Surg. 25: 958 (1932).

3. Maruon, $P$. Sur le traitement des pancréatities aîgues par les infiltrations splanchniques. Lyon Chir. 40: 315 (1945).

4. De Takats, G. \& Walter, L. E. Treatment of Pancreatic Pain by Splanchnic Nerve Section. Surg. Gynec. \& Obst. 85: 742 (1947).

5. GaGE, M. Quoted by A. Ochsner in Discussion. Ann. Surg. 128: 637 (1948).

6. Orr, R. B. \& Warren, K. W. Continuous Epidural Analgesia in Acute Pancreatitis. Lahey Clin. Bull. 6: 204 (1950).

7. Berk, J. E. \& Kruperman, L. W. The Use of Fractional Epidural Block in the Management of Acute Pancreatitis. Am. J. Med. Sc. 334: 507 (1952).

8. Goodman, L. S. \& GrLman, A. The Pharmacological Basis of Therapeutics, 3rd edition. New York: MacMillan. (1965).

9. SkInNER, B. S. A New Epidural Cannula. Canad. Anaesth. Soc. J. 13: 622 (1966).

10. Gotresman, J.; CAsten, D.; \& Ber.LER, A. J. Changes in the Electrocardiogram Induced by Acute Pancreatitis: J.A.M.A. 123: 892 (1943).

11. Elitotr, D. W. Treatment of Acute Pancreatitis with Albumin and Whole Blood. A,M.A. Arch. Surg. 7: 573 (1957).

12. Stephenson, H. E.; Pfefrer, R. B.; \& Seypor, G. M. Acute Haemorrhagic Pancreatitis: Report on a Case with Cortisone Treatment. A.M.A. Arch. Surg. 65: 307 (1952).

13. Edmondson, H. A.; Berne, C. J.; Homann, R. E.; \& Wertman, M. Calcium, Potassium, Magnesium and Amylase Disturbances in Acute Pancreatitis. Am. J. Med, 12: 34 (1952).

14. Jones, C. A. Medical Management of Pancreatitis. A.M.A. Arch. Int. Med. 96: 332 (1956). 